\title{
UNIDADES GEOAMBIENTAIS NA BACIA HIDROGRÁFICA DO RIO ITU - OESTE DO ESTADO DO RIO GRANDE DO SUL, BRASIL
}

\author{
Romario Trentin ${ }^{1}$ \\ Luís Eduardo de Souza Robaina ${ }^{2}$
}

Resumo: Os estudos ambientais, que buscam o conhecimento dos recursos e as fragilidades do meio, fazem parte dos trabalhos do laboratório de geologia ambiental (LAGEOLAM UFSM) durante os últimos 15 anos. O oeste-sudoeste do estado do Rio Grande do Sul representa uma área de grande degradação ambiental com acelerados processos de erosão, voçorocamento, e processo de arenização. O presente trabalho analisa e mapeia unidades geoambientais na bacia hidrográfica do Rio Itu, usando uma escala de mapeamento de 1:50.000. Os componentes geoambientais representam uma interação entre as características do meio físico (relevo, geologia, drenagem, solos, precipitação, feições superficiais) e o uso e ocupação da terra. Foram definidas 9 unidades com características homogenias quanto aos processos de dinâmica superficial, que são: unidade de depósitos recentes, colinas de arenito, colinas de rochas vulcânicas, topos planos, morrotes de arenito, morrotes de rocha vulcânica, relevo escarpado, uso urbano, processos de arenização. Este mapa serve de ferramenta em projetos de desenvolvimento regional e gerenciamento de recursos.

Palavras-Chave: Mapeamento; Unidades Geoambientais; Dinâmica Superficial.

\section{GEOENVIRONMENTAL UNITS IN HIDROGRAPHIC BASIN OF THE ITU RIVER - WEST OF THE STATE OF RIO GRANDE DO SUL, BRASIL}

\begin{abstract}
Environmental studies, seeking knowledge of resources and the weaknesses do part of the work of Environmental Geology Laboratory (LAGEOLAM - UFSM) during the past 15 years. The west-southwest of Rio Grande do Sul represents an area of great environmental degradation with accelerated processes of erosion, gullies, and sands process. This paper analyzes and maps geo-environmental units in Itu River basin, using a mapping scale of 1:50,000. The components represent a geo-environmental interaction between the characteristics of the physical environment (topography, geology, drainage, soils, precipitation, surface features) and the use and occupation of land. The work defined 9 units as those with homogeneous characteristics from dynamic surface processes, which are: unity of recent deposits, sandstone hills, hills of volcanic rocks, flat tops, sandstone buttles of the sandstones, buttles of volcanic rock, steep topography, urban use, processes of sands. This map serves as a tool in regional development projects and resource management.
\end{abstract}

Key-Words: Mapping; Geoenvironmental Units; Dynamic Surface.

\footnotetext{
${ }^{1}$ Graduação em Geografia, Mestrado em Geografia, Doutorado em Geografia, Professor Adjunto da Universidade Federal da Santa Maria (UFSM) - E-mail: tocogeo@yahoo.com.br

${ }^{2}$ Graduação em Geologia, Mestrado em Geociências, Doutorado em Geociências, Professor/pesquisador Colaborador da Universidade Federal do Rio Grande do Sul e Professor Associado da Universidade Federal de Santa Maria (UFSM) - E-mail: lesrobaina@yahoo.com.br DOI: 10.7154/RDG.2012.0023.0012
} 


\section{INTRODUÇÃO}

O processo de mapeamento geoambiental tem como rotina fundamental a divisão da área em unidades, de acordo com a variação de seus atributos. As unidades representam áreas com heterogeneidade mínima quanto aos atributos e, em compartimentos com respostas semelhantes frente aos processos de dinâmica superficial.

A cartografia geoambiental, de desenvolvimento mais recente no Brasil, começa a ganhar importância nos últimos anos e, seu desenvolvimento metodológico vem se aprimorando, com vários pesquisadores de diversas instituições produzindo documentos de zoneamento geoambiental.

No Rio Grande do Sul, nas regiões Sudoeste e Oeste, o tema de degradação ambiental ganha significativa importância na medida em que o estudo destas áreas degradadas vem ao encontro de uma das mais significativas preocupações ecológicas no Estado. Os dados cartográficos em escalas maiores são pouco disponíveis, e por isso o entendimento do desenvolvimento dos processos de dinâmica superficial ainda necessita ser investigados.

O estudo da região oeste têm importantes contribuições como as de Souto (1985), Suertegaray (1992), Suertegaray et al. (2001), Verdum (1993) e Verdum (1997).

$\mathrm{Na}$ linha de mapeamentos e análises morfométricas, cita-se o Laboratório de Geologia Ambiental, que tem desenvolvido trabalhos nesta área, conforme pode-se destacar os mapeamentos Geológico-Geomorfológico realizados por Paula (2002), Cardoso (2003), Corrêa (2004), bem como das análises morfométricas de bacias hidrográficas realizadas por Sangoi et al. (2003) e Kulmam (2004).

O presente trabalho tem por objetivo definir unidades geoambientais, na bacia hidrográfica do Rio Itu, em escala 1:50.000, com a interpolação de várias informações referentes ao meio físico e do uso e ocupação da terra.

O Rio Itu é afluente da margem direita do Rio Ibicuí e localiza-se no oeste do Rio Grande do Sul, estendendo-se pelos municípios de São Francisco de Assis, Manuel Viana, Itaqui, Unistalda, Maçambará, São Borja e Santiago. Com uma área de 2.809,61 km², esta bacia hidrográfica está inserida entre as coordenadas geográficas 54 52' 20" a 55은 53' 15” de longitude e 28 58' 00" a 29o 24' 40' de latitude sul (Figura 1). 


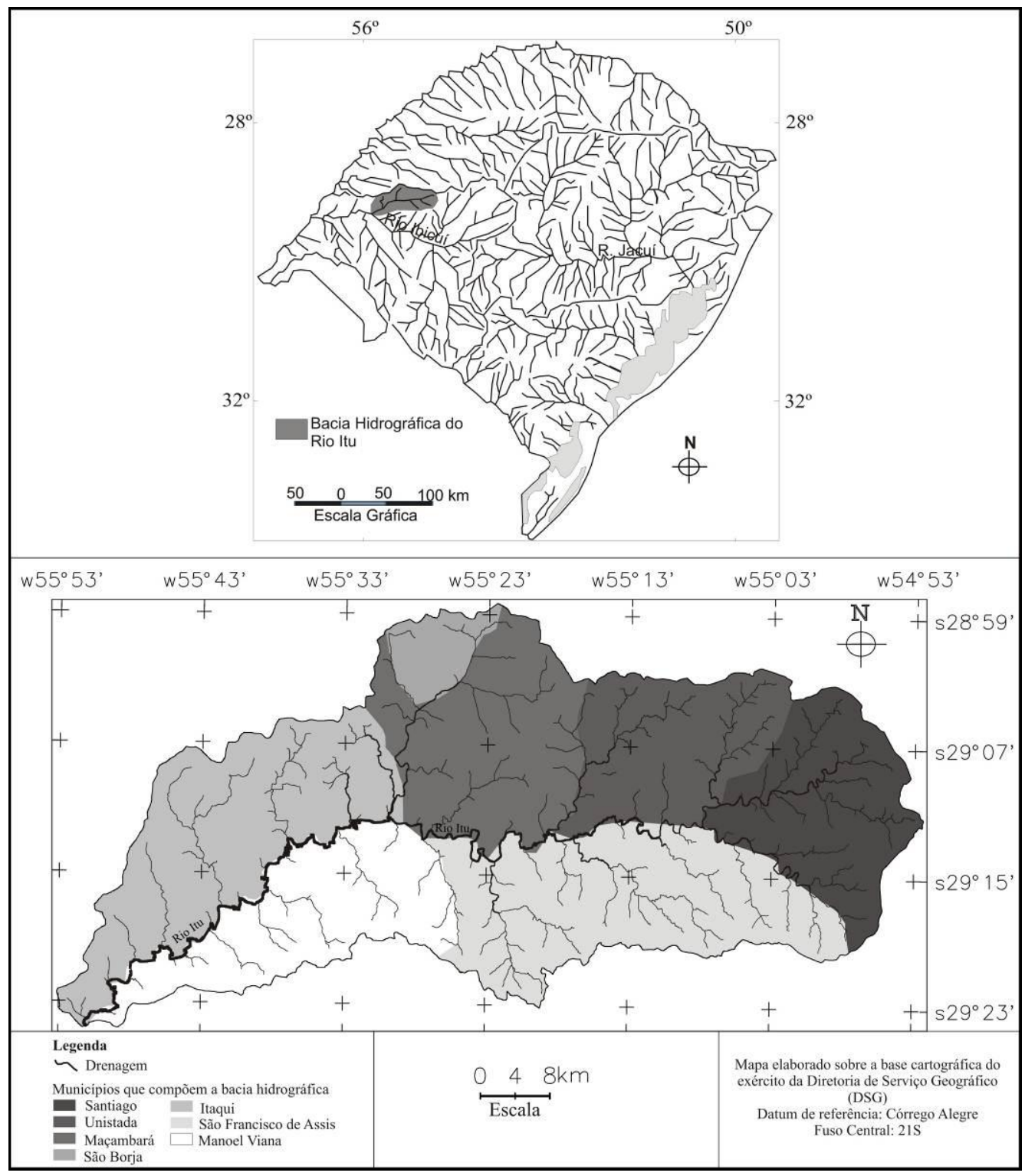

Figura 1 - Localização da área de estudo (Elaboração: Os autores)

\section{PROCEDIMENTOS METODOLÓGICOS}

Os procedimentos metodológicos utilizados na elaboração do trabalho, estão baseados na proposta de mapeamento geoambiental elaborada pelo LAGEOLAM/UFSM, podendo ser encontrada em Trentin e Robaina (2005) que consiste em uma metodologia baseada principalmente na proposta de Ross (1992), porém com uso de uma série de atributos e procedimentos bastante particulares, definidos nesta metodologia.

As cartas base são os levantamentos topográficos do exército em escala 1:50.000. Foram utilizadas também fotografias aéreas oblíquas de baixa altitude, obtidas com um sobrevôo 
da área, imagens de satélite LANDSAT 7 ETM+ e mapa de solos em escala 1:250000 de Streck et al. (2002).

Os trabalhos de campo foram realizados de forma investigativa buscando a identificação da litologia da área, bem como a identificação dos tipos de solo e forma de uso e ocupação da bacia hidrográfica do Rio Itu.

Os estudos de atributos do clima foram realizados em quatro estações próximas a bacia, pertencentes às redes de estações meteorológicas de vários institutos de meteorologia e no caso mais especificamente da EMBRAPA (2006) (Empresa Brasileira de Pesquisa Agropecuária) e ANA (2006) (Agência Nacional de Águas), sendo uma localizada no município de São Borja, uma em Maçambará, uma em Manoel Viana e outra em Alegrete e com base em Berlato e Fontana (2003).

Para a elaboração dos mapas e interpolação dos dados, utilizou-se o software Spring 4.2 desenvolvido pelo Instituto Nacional de Pesquisas Espaciais (INPE) e Corel DRAW 12.

As categorias de informação que foram analisadas e levantadas foram definidas através da metodologia desenvolvida pelo LAGEOLAM (TRENTIN; ROBAINA, 2005), que são as seguintes: classes de documentos básicos; derivados; auxiliares e interpretativos.

Os estudos para elaboração do mapa Geoambiental iniciam com um grupo de documentos básicos. Nesta etapa são obtidos os mapas topográficos, carta imagem e demais mapas préexistentes. As informações climáticas e de uso e ocupação são obtidas através de pesquisa em estações meteorológicas (na área de trabalho e no seu entorno) e órgãos públicos e privados.

Os documentos derivados são produtos da integração de dados e da compilação de mapas básicos. A rede hidrográfica é estudada através do fator forma da bacia, hierarquia e magnitude fluvial, densidade de drenagem e o padrão de drenagem.

A forma da bacia, hierarquia e magnitude fluvial indicam a energia da drenagem, sua capacidade de transporte, erosão e deposição. O padrão e densidade da drenagem apresentam uma forte relação com a tectônica e a capacidade de infiltração das rochas e solos.

O estudo do relevo parte da análise e cartografia de suas características principais, determinadas pela hipsometria, declividade, amplitude, comprimento e perfis de vertente. Christofoletti (1980) indica que o estudo das vertentes representa um dos mais importantes setores da geomorfologia, englobando a análise de processos e formas. 
Nesta etapa de desenvolvimento dos documentos derivados, é elaborado o mapa de uso da terra, com base na carta imagem, que reflete áreas distintas da paisagem em um determinado momento.

Os documentos interpretativos são realizados a partir das informações e dos levantamentos, contidos nos documentos básicos e derivados, apoiados por trabalhos de campo.

O mapeamento litológico apresenta através de uma análise integrada, a identificação e definição de diferentes tipos de rochas que compõem o substrato do meio físico e os principais lineamentos estruturais.

O mapa de unidades de relevo identifica as principais características das vertentes e apresenta a distribuição das formas de relevo. A delimitação de unidades de relevo parte da definição dos parâmetros de vertente e de sua influência nos processos de dinâmica superficial.

Os solos são descritos por seus aspectos físicos, como textura, estrutura e espessura. A variedade de tipos de solo e sua distribuição espacial influenciam a eficiência dos usos e ocupações e a intensidade dos processos superficiais.

As feições superficiais identificadas são representadas na forma de polígonos, linhas ou pontos. Caracterizam-se como naturais e/ou antrópicas e englobam registros de processos erosivos acelerados, depósitos de encosta e fluviais, barragens, pedreiras, saibreiras, entre outras.

O resultado final do cruzamento destas informações ocorre através da sobreposição dos mapas temáticos (mapas básicos, derivados e interpretativos), gerando o mapeamento e análise das Unidades Geoambientais que são formas do terreno resultantes da ação dos agentes internos e externos, responsáveis pela delimitação de regiões constituídas de atributos naturais ou antrópicos distintos e característicos,sendo definidas suas potencialidades e fragilidades ambientais.

\section{DISCUSSÃO DOS RESULTADOS}

Este trabalho corresponde a síntese de uma dissertação de mestrado, desta forma os resultados aqui apresentados são concentrados nas informações da análise geoambiental, maiores detalhamento sobre as informações trabalhadas podem ser consultadas em Trentin (2007). 
Os atributos do meio físico utilizados para a análise Geoambiental foram: rede hidrográfica, formas do relevo, substrato geológico, condições climáticas, tipos de solo, uso e ocupação da terra, feições superficiais e características ambientais marcantes.

Na definição de uma unidade homogênea pode-se utilizar um único atributo ou um grupo deles, que é a base para a análise de uma área.

\section{Análise do Meio Físico}

Diminuiu-se o número de sub-itens fazendo uma análise geral dos atributos do meio físico. $\mathrm{A}$ bacia hidrográfica do Rio Itu apresenta uma hierarquia fluvial de 7ạ ordem. Estende-se na direção Leste - Oeste por $116.45 \mathrm{~km}$ até sofrer uma inflexão para o sul, seguindo até sua foz na direção Nordeste - Sudoeste por mais $83.9 \mathrm{~km}$, onde deságua junto ao Rio Ibicuí. A Tabela 1 mostra os dados morfométricos analisados na bacia hidrográfica do Rio Itu, nos diferentes atributos analisados.

Tabela 1 - Atributos da análise morfométrica da rede de drenagem:

\begin{tabular}{ll}
\hline ATRIBUTOS & MORFOMETRIA \\
\hline Hierarquia & $7 \underline{\text { a ordem }}$ \\
\hline Extensão do Canal Principal & $200.35 \mathrm{~km}$ \\
\hline Área da Bacia Hidrográfica & $2.809,6 \mathrm{~km}^{2}$ \\
\hline Perímetro da Bacia Hidrográfica & $328,79 \mathrm{~km}$ \\
\hline Índice de Circularidade & 0,32 \\
\hline Comprimento Total dos Cursos d'Água & $4.834,4 \mathrm{~km}$ \\
\hline Magnitude & $3.266 \mathrm{canais}$ \\
\hline Densidade de Drenagem & $1,72 \mathrm{~km} / \mathrm{km}^{2}$ \\
\hline
\end{tabular}

Fonte: Os autores

A bacia foi dividida em três setores: setor $A$, correspondendo à do alto curso do Rio Itu, se estende do topo do planalto até a porção, na qual, o canal principal adquire a hierarquia de 6a (sexta) ordem, pela confluência da Sanga Águas Claras com Rio Itu; o setor B, correspondendo ao médio curso da bacia hidrográfica, estende-se desde a porção em que o Rio Itu se torna de 6a ordem, até a porção onde o canal principal adquire a hierarquia de 7ạ ordem e; o setor $C$ porção do baixo curso da bacia hidrográfica do Rio Itu, se apresenta a partir da porção em que o canal principal adquire a hierarquia de 7ạ ordem, e estende-se até desaguar junto ao Rio Ibicuí. Este setor apresenta uma inflexão para sul, em relação ao restante da bacia hidrográfica, sendo assim, o canal principal passa a ter seu percurso na 
direção nordeste-sudoeste, obedecendo à linha de falhamentos predominantes da área de estudo (Figura 2).

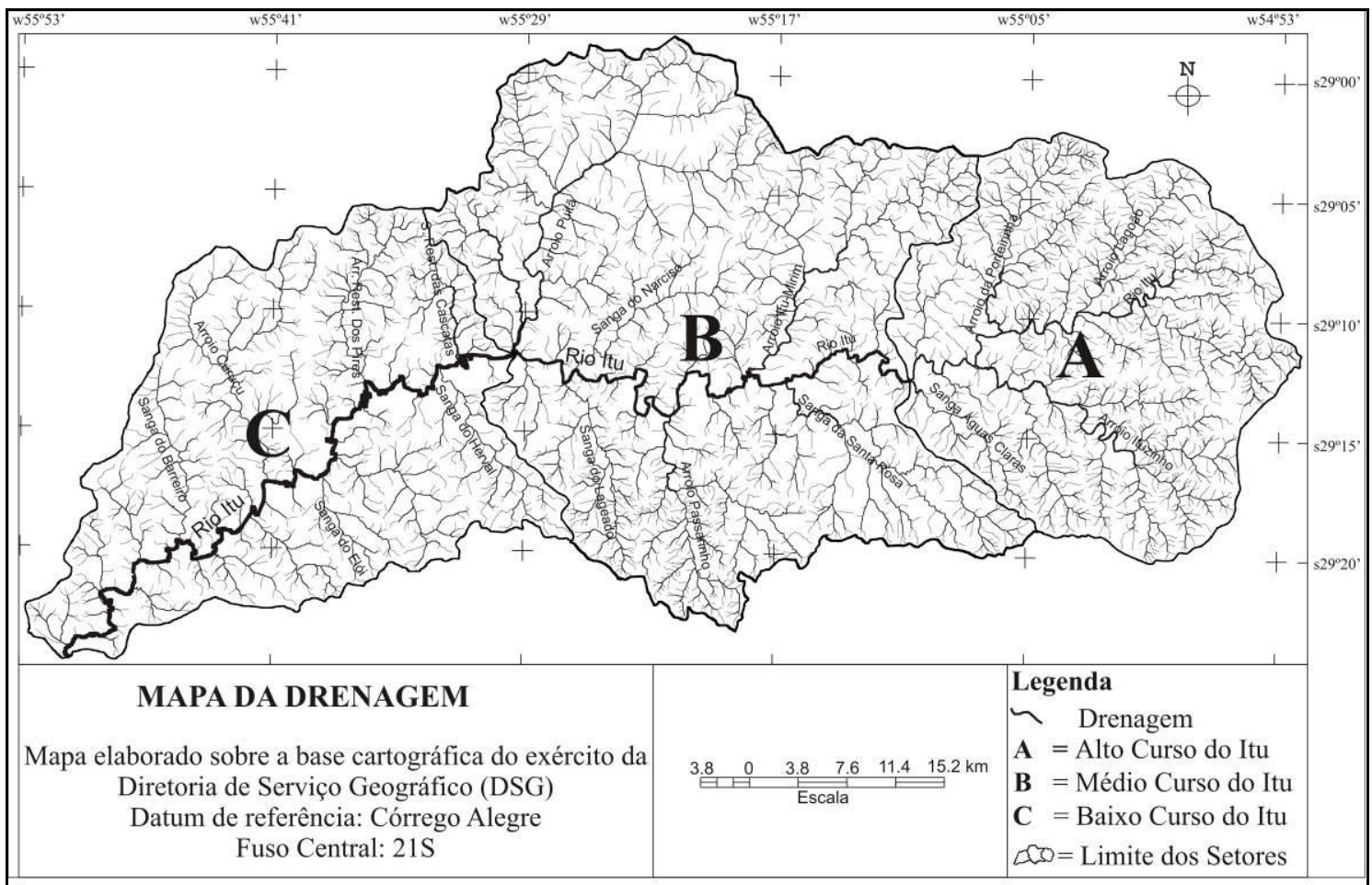

Figura 2 - Mapa dos setores da drenagem da bacia hidrográfica do Rio Itu (Elaboração: Os autores)

O relevo está caracterizado pela inclinação das vertentes e pela altimetria, definindo sete unidades homogêneas, apresentadas de forma resumida na Tabela 2 e identificadas na Figura 3.

Tabela 2 - Características das unidades de relevo da bacia hidrográfica do Rio Itu

\begin{tabular}{|c|c|c|c|c|c|c|}
\hline $\begin{array}{l}\text { Unidade } \\
\text { Relevo }\end{array}$ & de & Declividade & Altitude & $\begin{array}{l}\text { Características do } \\
\text { Relevo }\end{array}$ & Área $\left(\mathrm{km}^{2}\right)$ & $\begin{array}{l}\% \text { da Área } \\
\text { total }\end{array}$ \\
\hline 1 & & $<2$ & $<80$ & Áreas Planas & 87,42 & 3,11 \\
\hline II & & $<5$ & $80-200$ & $\begin{array}{l}\text { Suavemente } \\
\text { Onduladas }\end{array}$ & 475,50 & 16,92 \\
\hline III & & \multirow[t]{2}{*}{$5-15$} & $<200$ & \multirow[t]{2}{*}{ Onduladas } & 1156,18 & 41,15 \\
\hline IV & & & $>200$ & & 286,64 & 10,05 \\
\hline $\mathrm{V}$ & & \multirow{3}{*}{$>15$} & $<200$ & \multirow{2}{*}{ Fortemente Ondulada } & 234,11 & 8,33 \\
\hline $\mathrm{VI}$ & & & $>200$ & & 448.21 & 15,45 \\
\hline VII & & & $>200$ & Escarpa & 121,51 & 7,06 \\
\hline
\end{tabular}




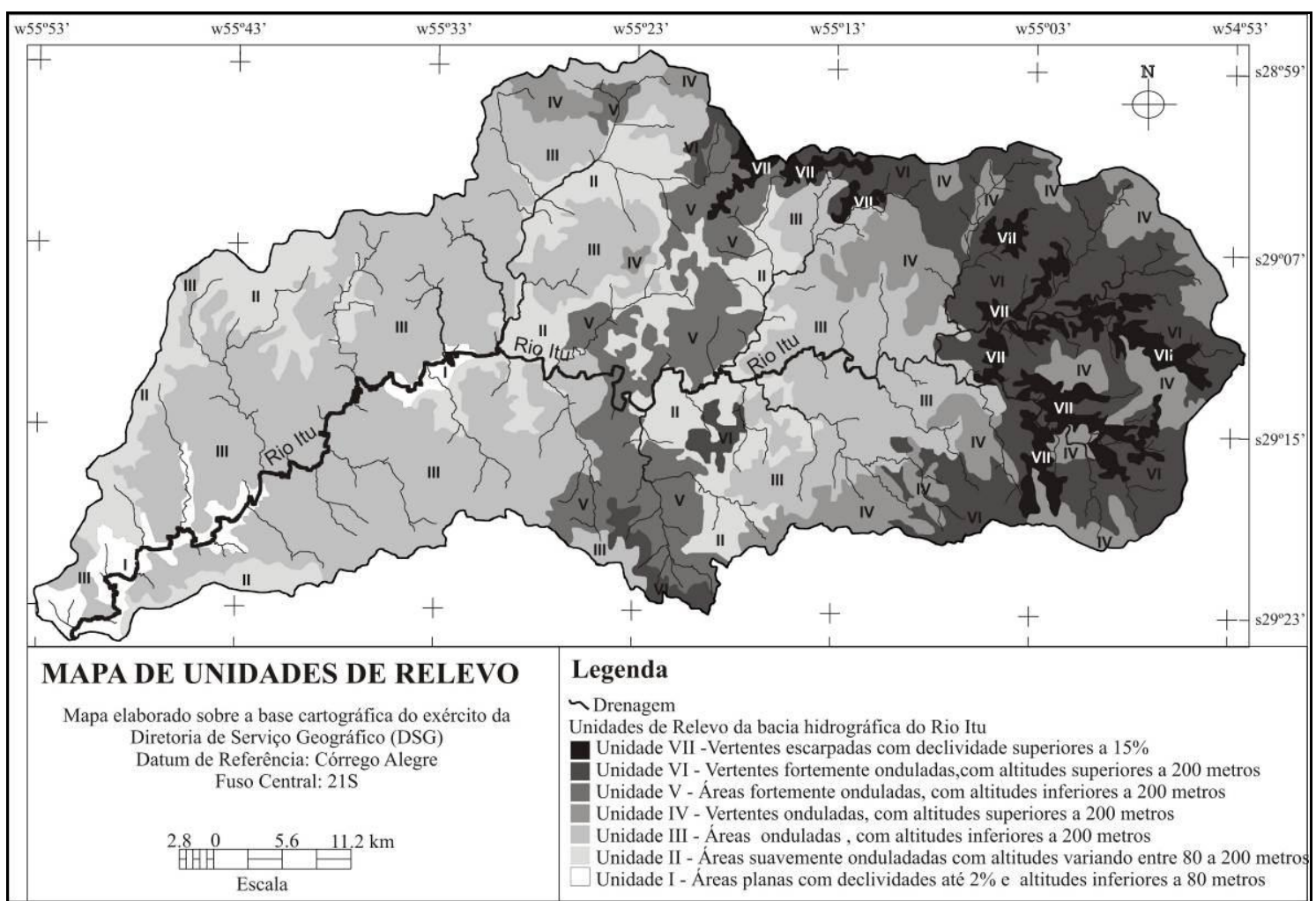

Figura 3 - Mapa de unidades de relevo da bacia hidrográfica do Rio Itu (Elaboração: Os autores)

Em relação as litologias foram determinados cinco blocos, conforme identifica-se na Figura 4, individualizados através de fraturamentos e falhamentos.

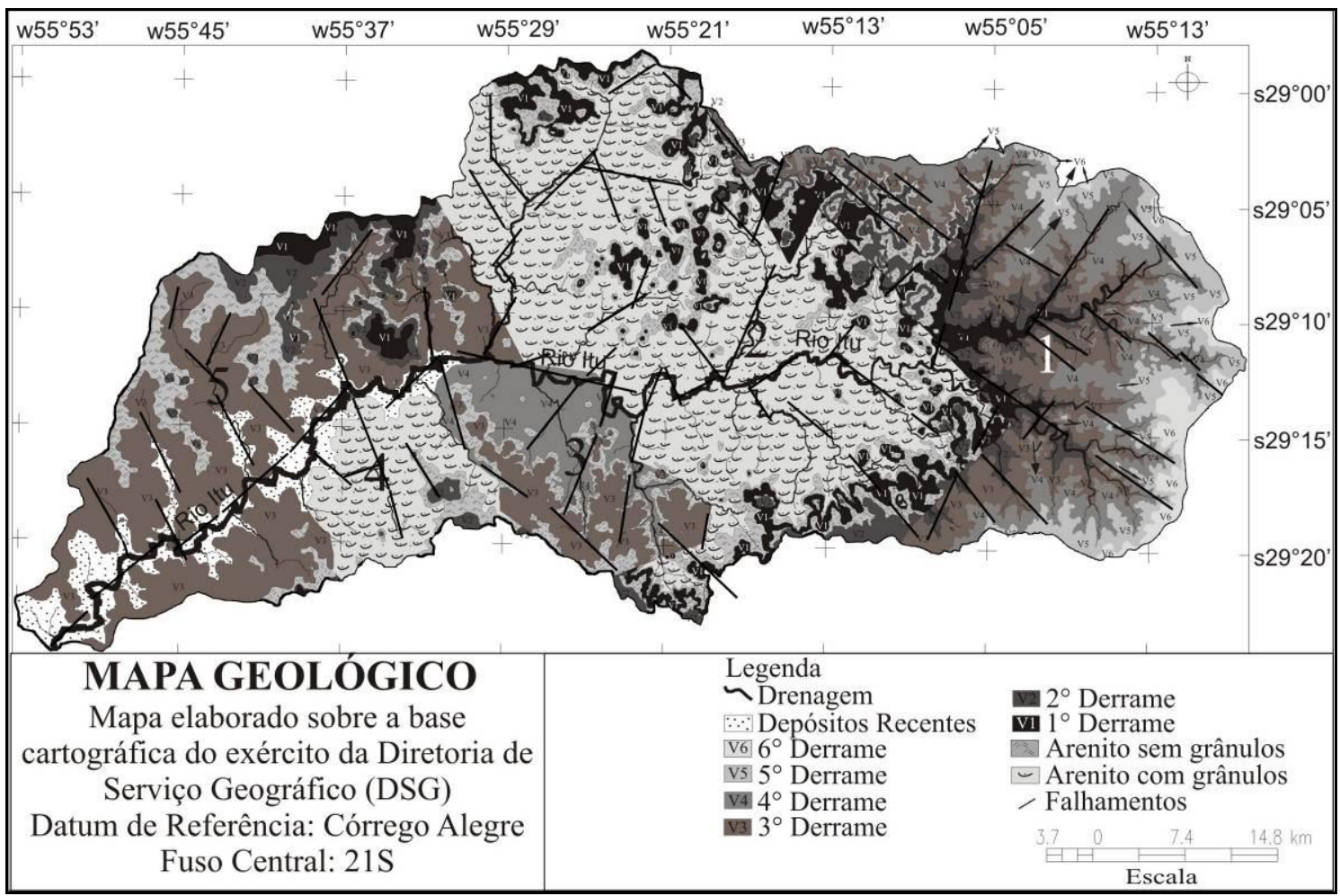

Figura 4 - Mapa litológico da bacia hidrográfica do Rio Itu (Elaboração: Os autores) 
O Bloco 1 é constituído quase que essencialmente de derrames vulcânicos, num total de seis, determinados em trabalhos de campo através de diferenças texturais e estruturais, com espessuras variando de 30 a 60 metros. Ocorrem duas camadas delgadas de arenito da Formação Botucatu (FB), variando de 10 a 20 metros de espessura, ocorrendo entre as cotas de 200 a 220 metros e de 250 a 270 metros na porção noroeste.

No Bloco 2 ocorre a predominância de arenitos com grânulos da Formação Guará (FG) com a presença ainda de duas camadas de arenito bem classificados (FB), sendo muito delgada com cerca de 10 metros de espessura nas cotas de 190 a 200 metros e a outra de 235 a 245 metros.

No Bloco 3 predominam os derrames vulcânicos com cerca de $76,7 \%$ da área, representado principalmente pelo 3o e 4ำ derrames encontrados na bacia hidrográfica do Rio Itu com espessura variando de 40 a 60 metros. Neste bloco já é evidenciada uma pequena área de depósitos recentes, associadas ao canal principal do Rio Itu.

No Bloco 4 ocorrem no topo das colinas arenito sem grânulos (FB) e rocha vulcânica, e no restante da área arenito com grânulos (FG). Os Depósitos Recentes estão associados ao canal principal do Rio Itu e seus Principais afluentes.

O Bloco 5 apresenta características semelhantes aos blocos 1 e 3, onde as rochas Vulcânicas são predominantes com apenas intercalações de arenitos da Formação Botucatú. Os derrames neste bloco são bastante variados quanto à espessura, pois encontra-se desde derrames delgados como é o caso do 20 derrame com apenas 15 metros, até cerca de 55 metros, caso do 1 o derrame. Por ser a área de baixo curso da bacia hidrográfica, ocorre a maior área de Depósitos Recentes.

As precipitações na área de estudo controlam a ação dos processos superficiais. A análise de dados podem ser visto na Figura 5. Não são observados variações da precipitação na bacia em estudo e a precipitação anual fica em torno 1509 mm, com os maiores índices de precipitação nos meses de abril e outubro e os menores nos meses de julho e agosto.

As temperaturas médias anuais na bacia hidrográfica variam em torno de $10^{\circ} \mathrm{C}$ nos meses mais frios e em torno de $32^{\circ} \mathrm{C}$ nos meses mais quentes.

A Figura 6 mostra a distribuição da precipitação na estação meteorológica de Alegrete nos anos de 2005 e 2006. Observa-se que no ano de 2005 as precipitações foram superiores ao ano de 2006, sendo que nesta estação meteorológica os registros indicam apenas o mês de janeiro com precipitações de 2006 sendo superiores as de 2005. 


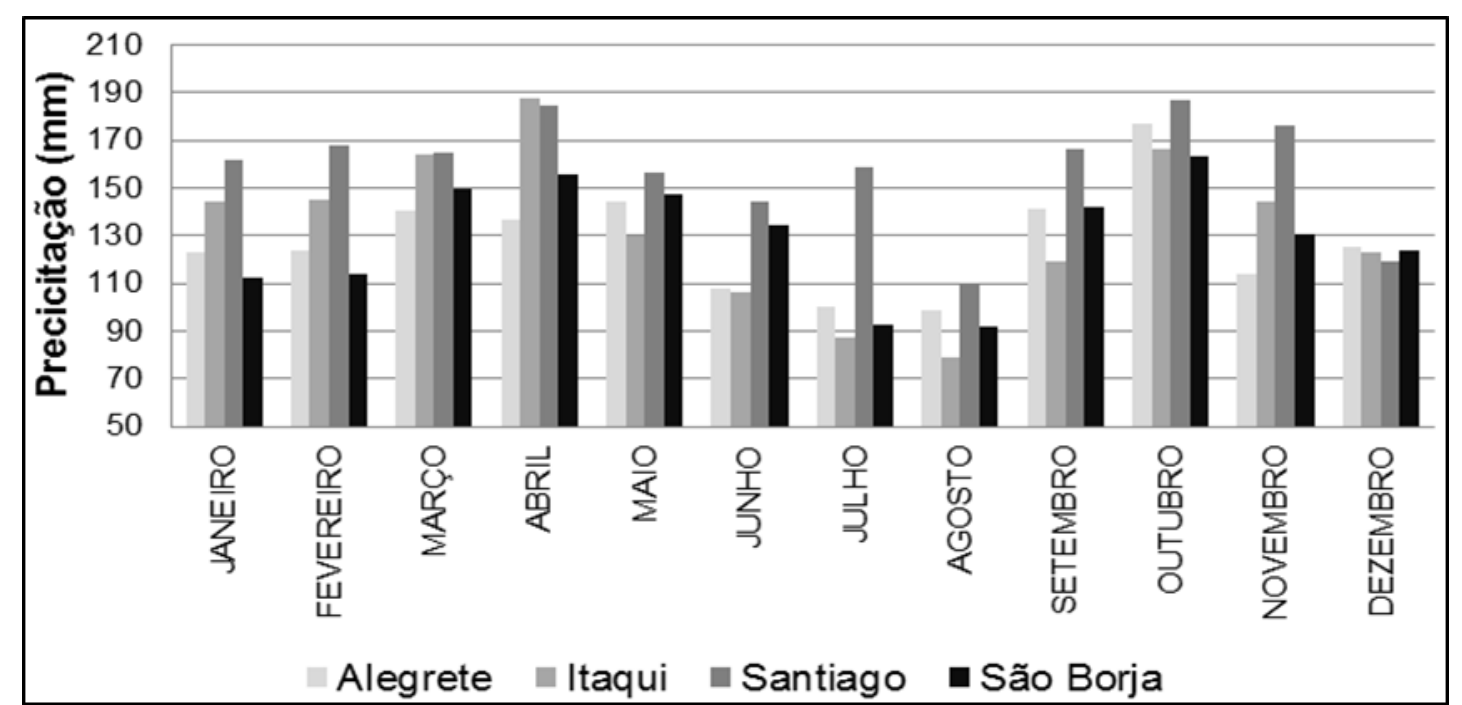

Figura 5 - Precipitação média mensal (mm) no período 1980 - 2007. (Elaboração: Os autores) Fonte: ANA (2006); EMBRAPA (2006).

O ponto de maior destaque é o mês de maio, pois no ano de 2005 , teve a maior precipitação do ano, com 228 mm e em 2006, teve a menor precipitação registrada, com apenas 5 mm.

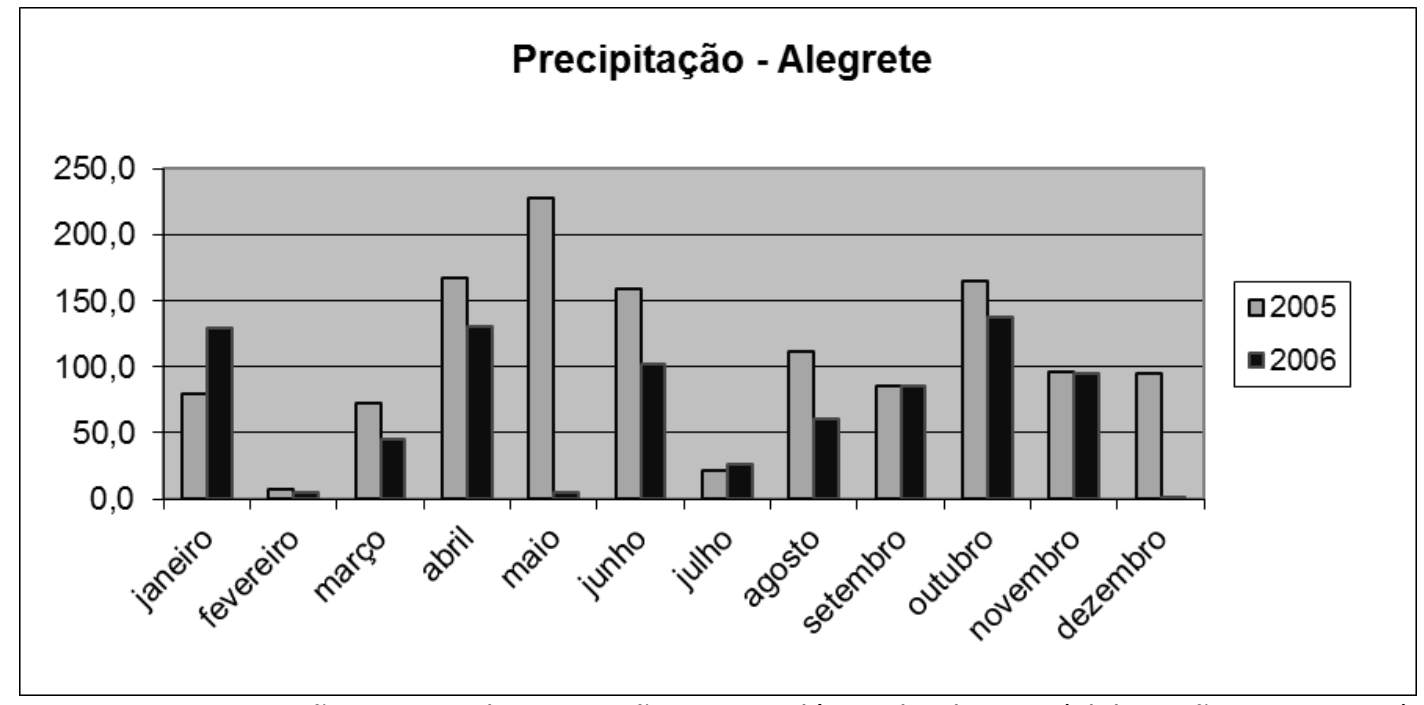

Figura 6 - Precipitações registrada na estação meteorológica de Alegrete (Elaboração: Os autores)

Estas grandes variações de precipitação nos anos de 2005 e 2006, com relação a média histórica possivelmente esta relacionada a ação do fenômeno "El Niño", ocorrido no ano de 2005.

Conforme visualiza-se na Figura 7, ocorre na bacia hidrográfica do Rio Itu 9 tipos de solos, com maior área ocupada pelos Latossolos Arenosos, seguidos pelos Nitossolos e pela associação de Cambissolos e Neossolos Litólicos. 


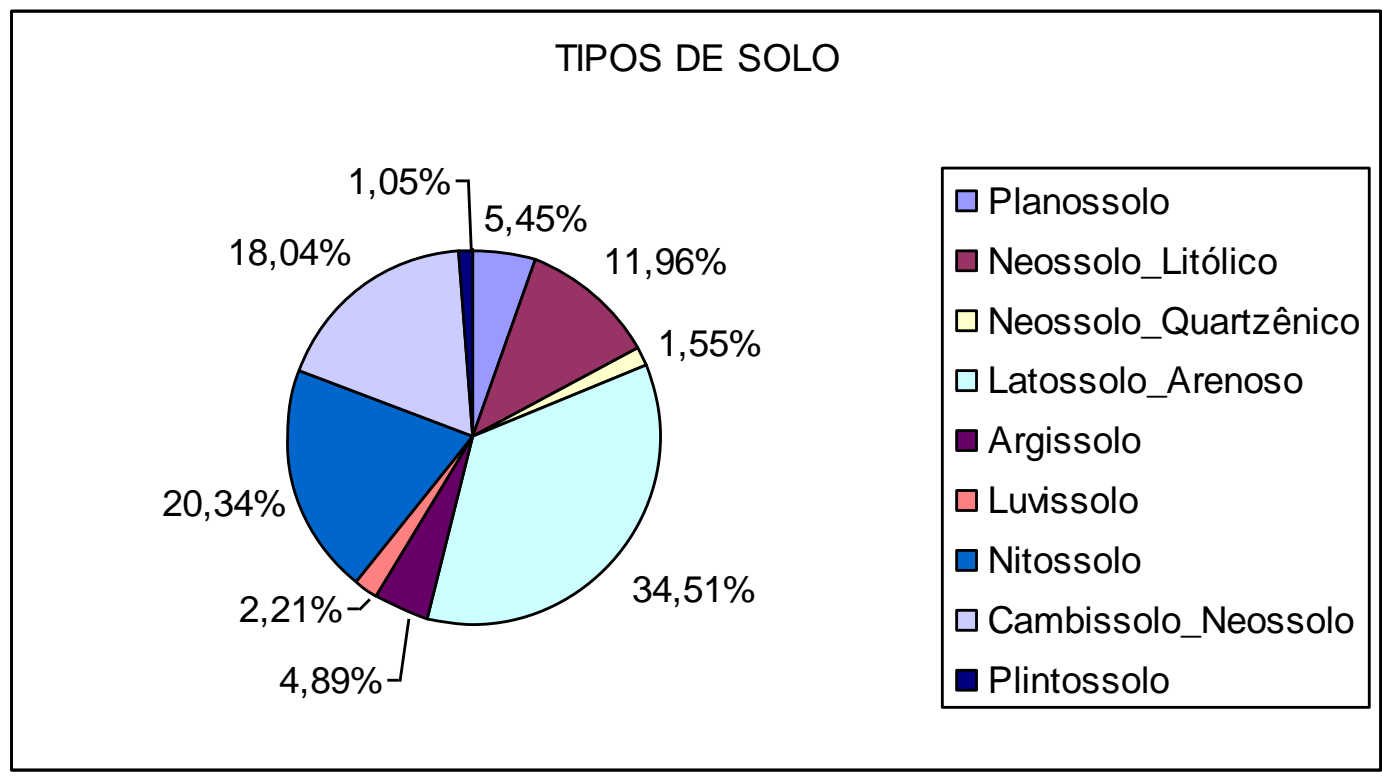

Figura 7 - Distribuição das porcentagens dos tipos de solo (Elaboração: Os autores)

Com relação aos solos podem ser identificados diversidades influenciadas pelas litologias e relevo. De maneira geral, junto ao relevo suavemente ondulado a ondulado, formam solos profundos, relevos planos em áreas junto à drenagem, solos hidromórficos e áreas com relevo declivosos geram solos pouco desenvolvidos. A Figura 8 mostra o mapa com a distribuição dos tipos de solo encontrados na bacia hidrográfica do Rio Itu.

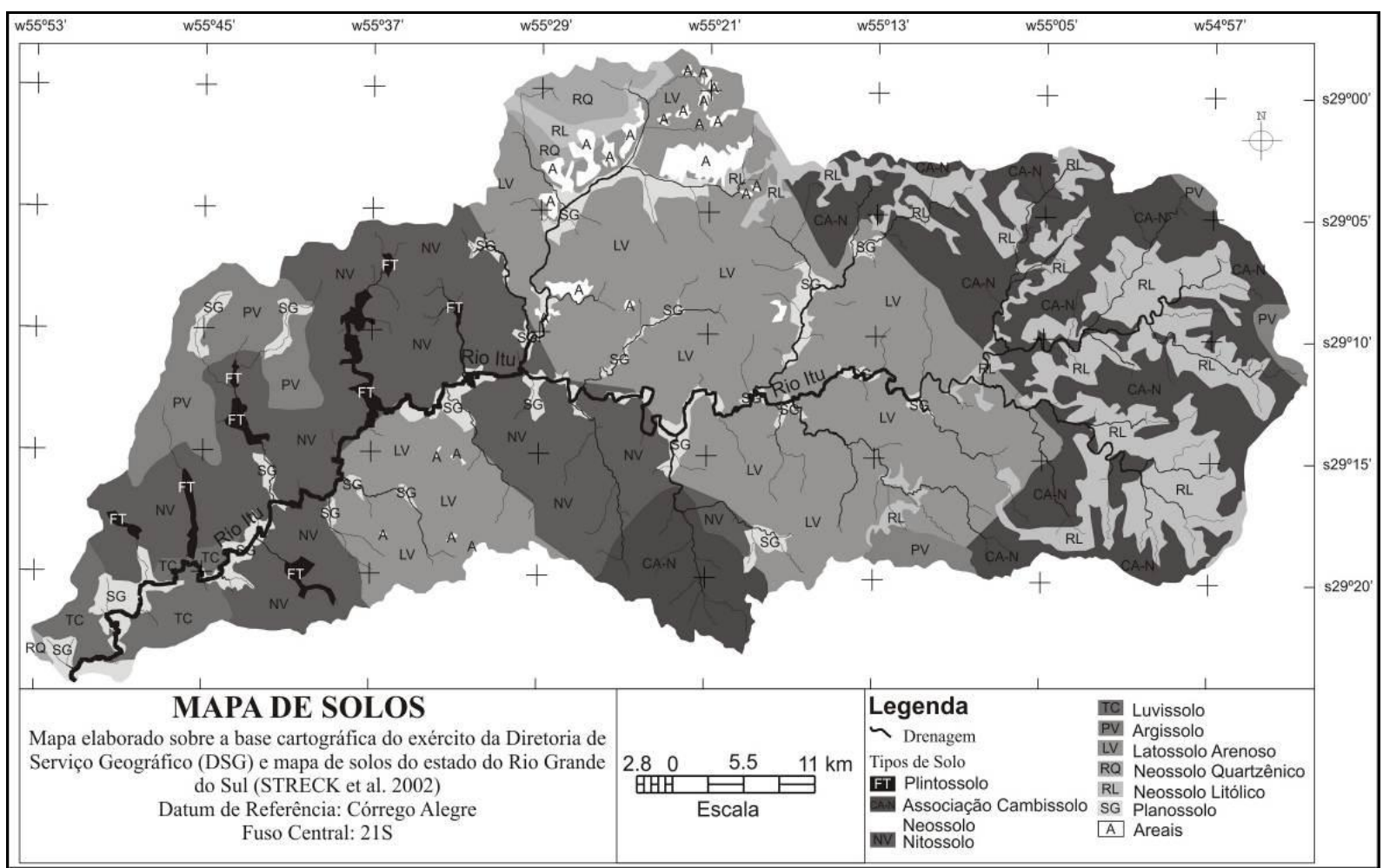

Figura 8 - Mapa de solos da bacia hidrográfica do Rio Itu (Elaboração: Os autores) 


\section{Uso e Ocupação da Terra}

Através da classificação da imagem de satélite LANDSAT 7 ETM+, de 03/03/2001 e de trabalhos de campo para identificação dos tipos de uso e ocupação da terra, gerou-se o mapa de uso e ocupação da terra da bacia hidrográfica do Rio Itu (Figura 9). A Tabela 3 mostra a distribuição das porcentagens e suas áreas dos oito tipos de uso e ocupação da terra individualizada na bacia hidrográfica.

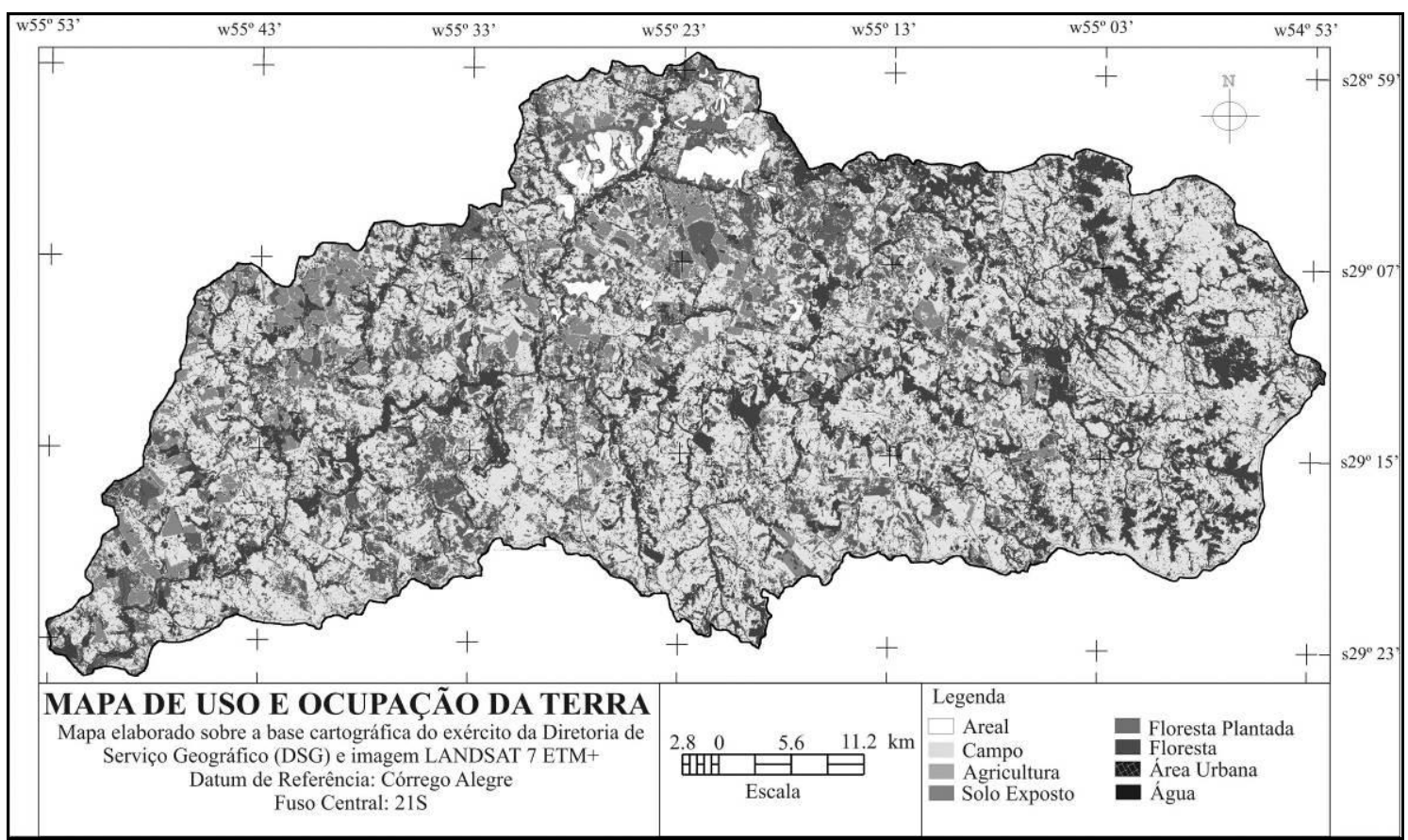

Figura 9 - Mapa de uso e ocupação da terra da bacia hidrográfica do Rio Itu (Elaboração: Os autores)

Tabela 3 - Área e porcentagem dos tipos de uso da terra

\begin{tabular}{lll}
\hline Tipo de Uso & Área $\left(\mathrm{km}^{2}\right)$ & Porcentagem (\%) \\
\hline Área Urbana & $1.371,08$ & 0,05 \\
\hline Areais & $40.262,54$ & 1,43 \\
\hline Floresta & $558.423,45$ & 19,87 \\
\hline Floresta Plantada & $5.354,79$ & 0,19 \\
\hline Água & $75.400,82$ & 2,68 \\
\hline Campo & $1.431 .406,80$ & 50,94 \\
\hline Solo Exposto & $558.007,86$ & 19,86 \\
\hline Agricultura & $139.644,76$ & 4,97
\end{tabular}

A bacia hidrográfica do Rio Itu é caracterizada pela presença predominante de campos, com cerca de $50 \%$ da área total. A atividade agrícola é significativa visto pela área plantada e pelo 
solo exposto para o plantio. As florestas que ocupam as áreas íngremes ocupam cerca de $20 \%$, ocorrem, também, as florestas plantadas, que situam-se junto aos areais, ocupando uma área de 0,19\%, e as áreas com processos de arenização 1,43\%. Ocorrem ain da duas pequenas áreas urbanas dos municípios de Santiago e Unistalda.

\section{Feições Superficiais e Características Ambientais Marcantes}

Dentre as feições superficiais marcantes, estão apresentados os campos de areia, as voçorocas e as áreas com floretas nativas preservadas. No mapa da Figura 10 estão definidas, também, as áreas de proteção permanente segundo a legislação vigente.

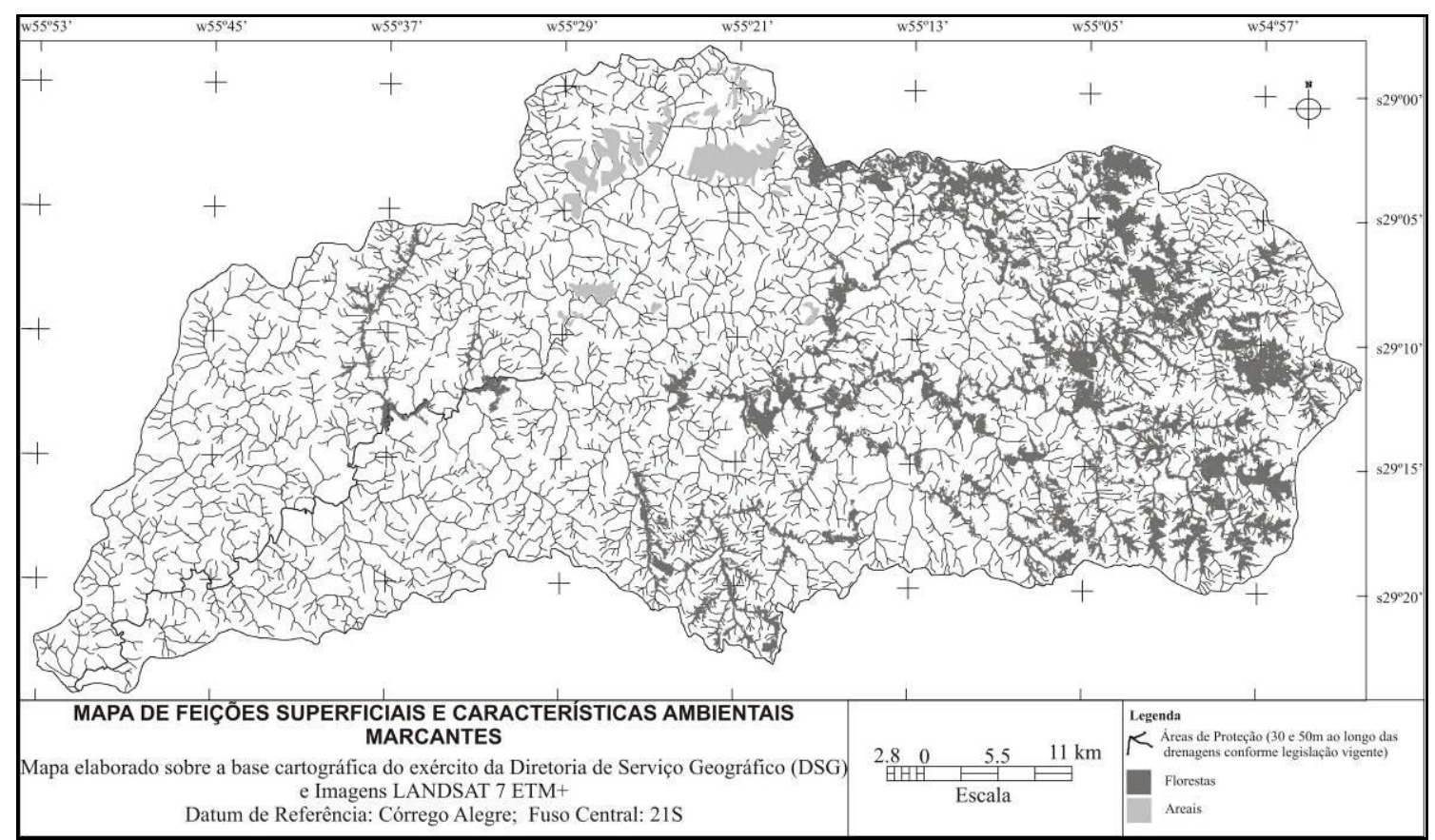

Figura 10 - Mapa de feições superficiais marcantes da bacia hidrográfica do Rio Itu (Elaboração: Os autores)

Os campos de areia marcam uma forma acelerada de erosão dos solos e que tem suscitado muita preocupação regional. Desenvolvem-se desde a cabeceira de drenagens desmatadas e, principalmente, em vertentes convexas junto à base das colinas, em geral, associados, na meia encosta, a arenitos pouco coesos.

As voçorocas são consideradas problema ambiental principalmente associado à degradação de terras e a exportação de sedimentos para as drenagens. Os principais processos de voçorocamento na bacia hidrográfica do Rio Itu estão associados aos substratos de arenitos friáveis, junto as cabeceiras de drenagem e algumas vezes ocorrem associados aos areais. 
Na região observa-se áreas medianamente preservadas e a maioria em recuperação pelo não uso do solo. A dificuldade de uso do solo tem favorecido a manutenção da vegetação arbórea em áreas com alta declividade. A cobertura vegetal atua como elemento importante na manutenção do equilíbrio da vertente, controlando significativamente a atividade erosiva e diminuindo a ação de movimentos de massa.

Quando avalia-se a vegetação ao longo dos cursos d'água observa-se que, na bacia, o uso do solo não respeita a legislação. Isso tem aumentado o assoreamento dos canais de drenagem, modificando o comportamento fluvial na região.

\section{Unidades Geoambientais}

Através do cruzamento dos dados dos três níveis de informações: básicas, derivadas e auxiliares e interpretativas, da bacia hidrográfica do Rio Itu, pôde-se definir 9 unidades homogêneas do terreno. A Figura 11 apresenta a distribuição espacial das unidades e o Quadro 1 apresenta um quadro resumo das principais características da cada unidade.

Unidade de Depósitos Recentes(I): esta unidade é caracterizada pela sua topografia plana, com declividades $<2 \%$ e as altitudes inferiores a 80 metros. Quanto à geologia, predominam os depósitos recentes do canal principal do Rio Itu e solos do tipo Planossolos, mal a imperfeitamente drenados. O uso predominante desta unidade é caracterizado pelas lavouras de arroz pela disponibilidade de água junto as drenagem e as próprias características do solo.

Esta unidade ocupa $3,11 \%$ da área total, e a grande preocupação junto a esta área é a preservação e/ou recuperação da mata ciliar, uma vez que o uso do solo pelas lavouras de arroz acaba removendo a vegetação ao longo dos cursos de água o que gera um sério problema ambiental, pois tornam-se vulneráveis aos processos de assoreamento e poluição com agrotóxicos e matérias oriundos destas lavouras.

Unidade de Colinas de Arenito(II): esta unidade é caracterizada por áreas planas a suavemente onduladas. Quanto à geologia, é definida como substratos areníticos e solos bem desenvolvidos sendo característicos os Latossolos arenosos. O uso típico desta unidade é uma associação de áreas de agricultura com campos de criação de gado, podendo ainda ser observada a presença de pequenos bosques de pinus e eucaliptus recobrindo áreas mais arenosas. 


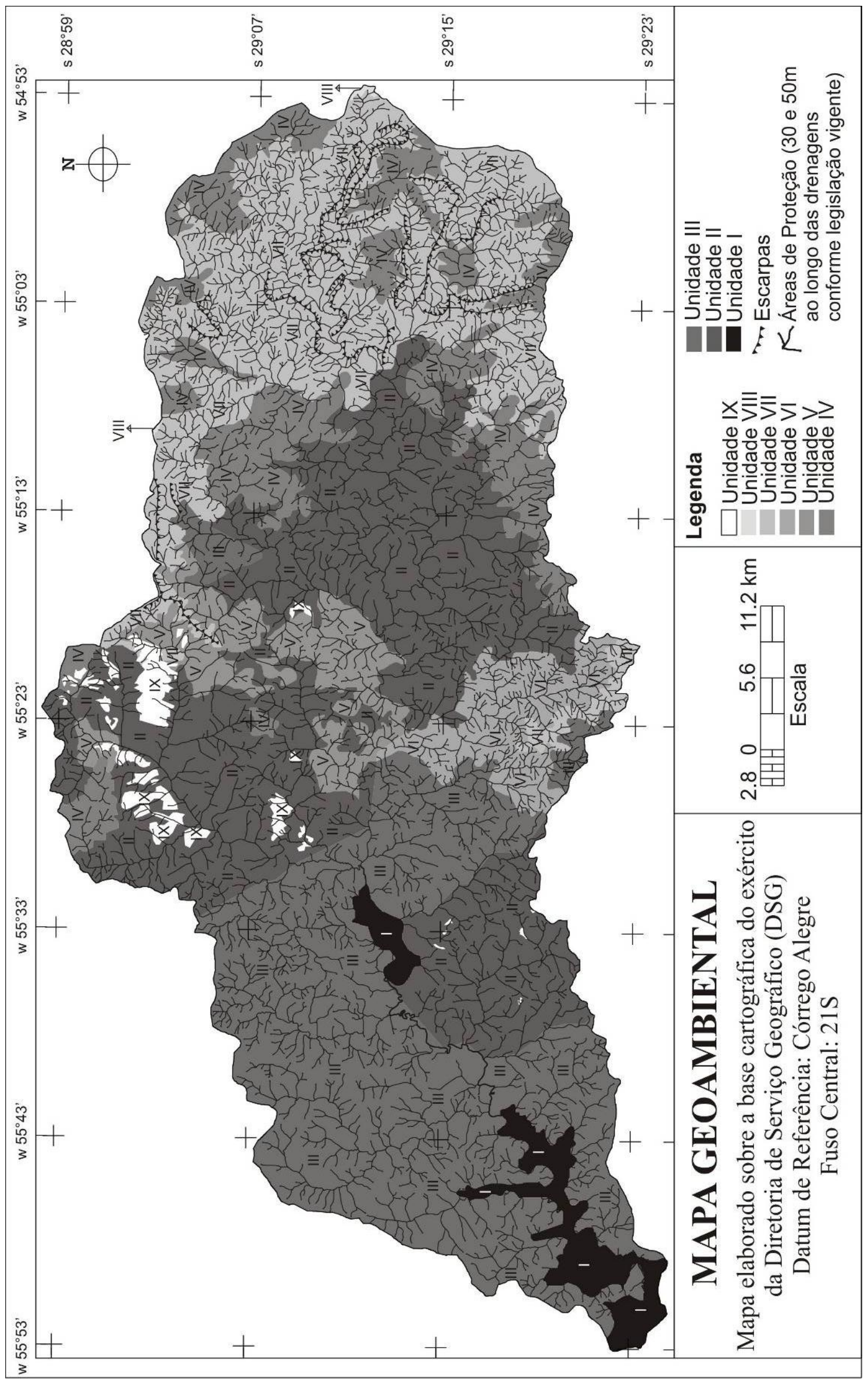

Figura 11 - Mapa de unidades geoambientais da bacia hidrográfica do Rio Itu (Elaboração: Os autores) 


\begin{tabular}{|c|c|c|c|}
\hline$\underline{x}$ & 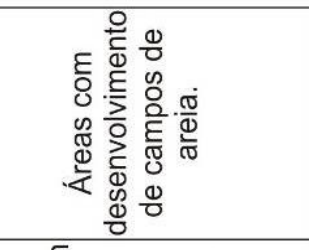 & 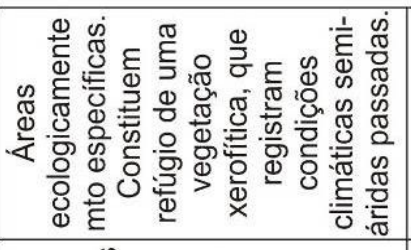 & 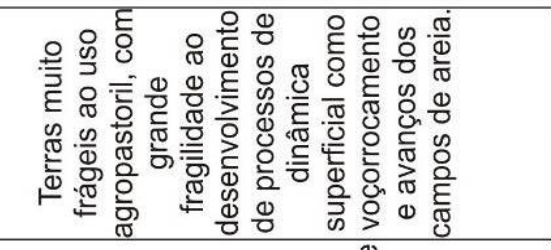 \\
\hline $\bar{\equiv}$ & 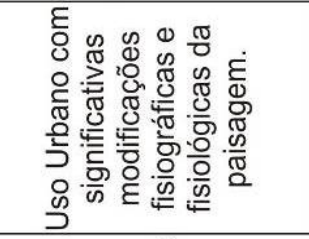 & 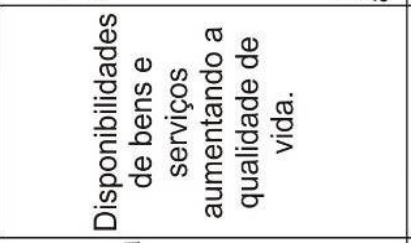 & 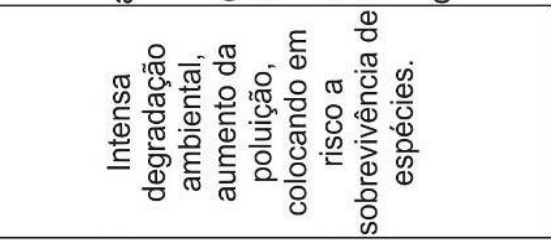 \\
\hline $\bar{\Sigma}$ & 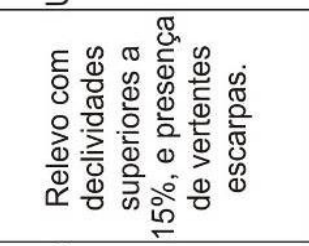 & 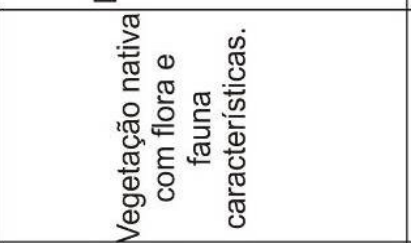 & 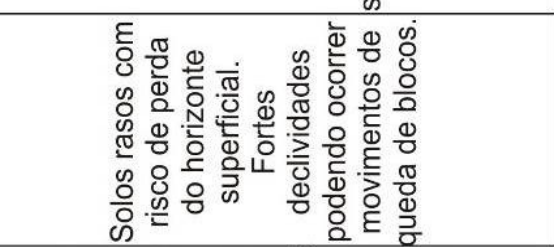 \\
\hline$>$ & 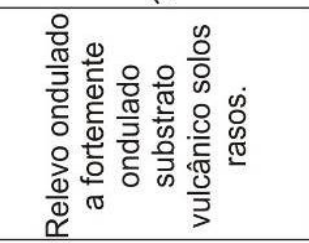 & 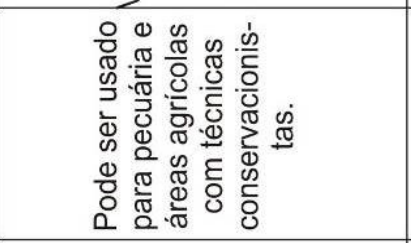 & 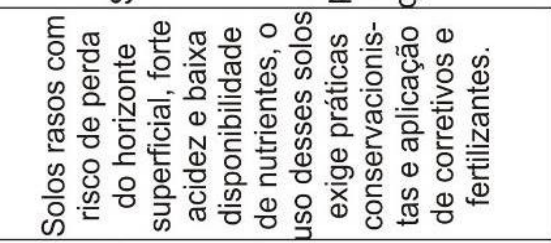 \\
\hline$>$ & 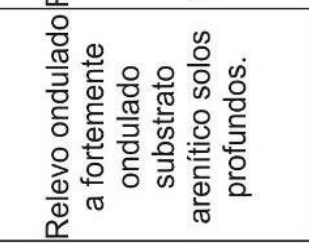 & 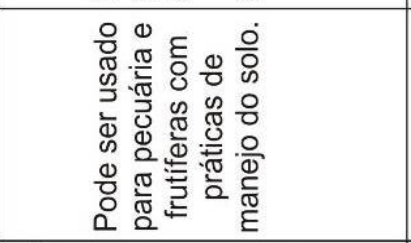 & 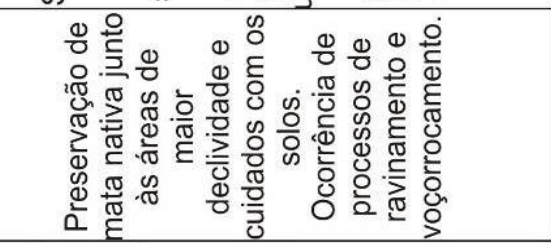 \\
\hline$\geq$ & 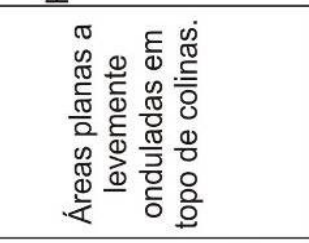 & 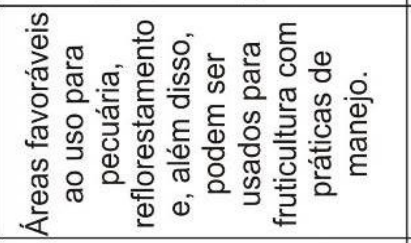 & 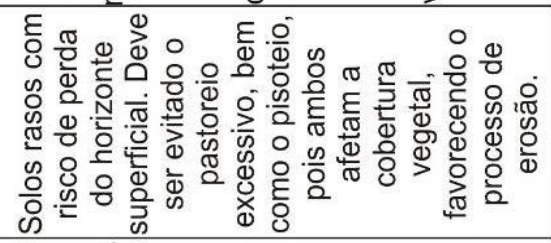 \\
\hline$\equiv$ & 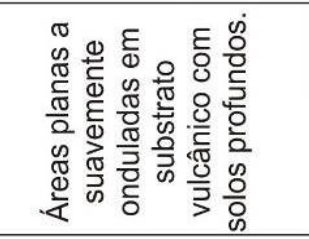 & 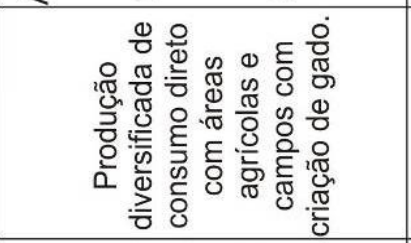 & 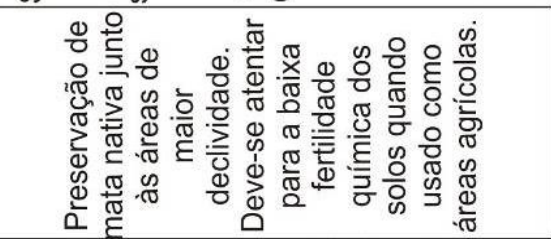 \\
\hline$=$ & 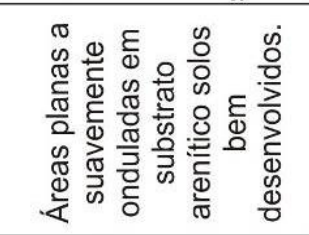 & 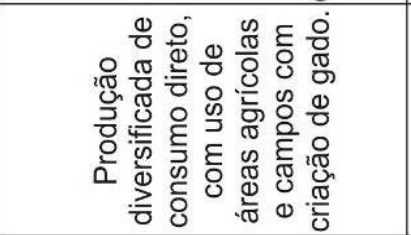 & 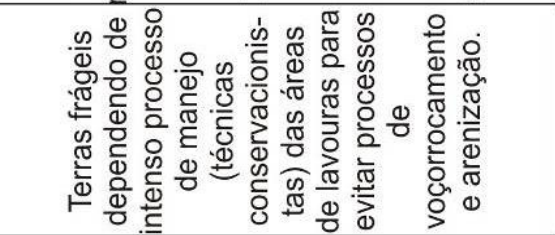 \\
\hline- & 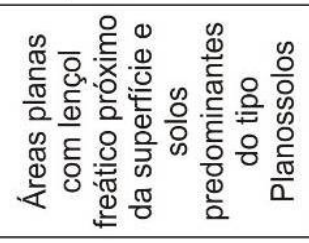 & 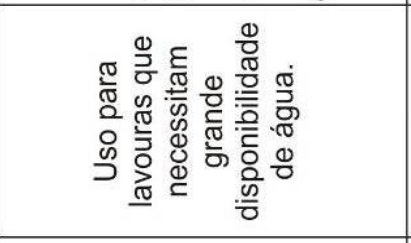 & 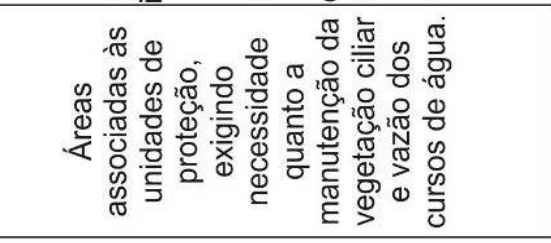 \\
\hline 恣 & 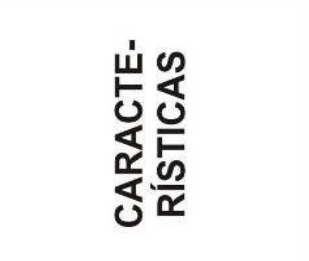 & 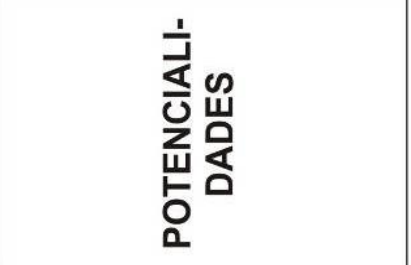 & 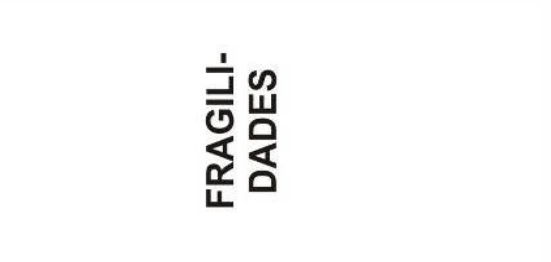 \\
\hline
\end{tabular}

Quadro 1 - Quadro síntese do mapa geoambiental (Elaboração: Os autores) 
Esta unidade é a que ocupa a maior área, com 29,78\% da área total, e a grande preocupação são os processos de voçorocamento e até mesmo processos de arenização. Estas áreas podem ser utilizadas com culturas de inverno e de verão, exigindo práticas conservacionistas adequadas, como por exemplo, plantio direto intercalado com plantas recuperadoras e canais escoadouros protegidos.

Unidade de Colinas de Rochas Vulcânicas(III): esta unidade é composta por áreas planas a suavemente onduladas, substrato geológico de rochas vulcânicas. Os solos são bem desenvolvidos, sendo mais característicos os Nitossolos e Argissolos. O uso desta unidade também se caracteriza pela associação de lavouras com campos de criação de gado, sendo comum os campos sujos, com vegetação mais vigorosa que as encontradas na unidade II em função das características do solo.

Esta unida de ocupa a segunda maior área com $26,60 \%$ do total, e a característica marcante é a presença junto às áreas de maior declividade da mata nativa, áreas estas que são protegidas pela legislação. É fundamental a manutenção destas vegetações, como forma de proteção contra os processos de dinâmica superficial.

Unidade com Topos Planos (IV): esta unidade apresenta as características de relevo plano a levemente ondulado, constituindo áreas de topo de colinas, no alto curso da bacia hidrográfica. O substrato sobre o qual esta unidade encontra-se são rochas vulcânicas do topo de planalto. Os solos são rasos, sendo característicos os Neossolos e associações de Neossolos e Cambissolos, pouco desenvolvidos. O uso desta unidade se caracteriza pela predominância de campos com criação de gado.

Esta unidade ocupa $10,77 \%$ da área total e não apresenta grandes problemas relacionados aos processos de dinâmica superficial. Os solos muito rasos podem apresentar dificuldades no desenvolvimento das mesmas.

Unidade de Morrotes de Arenito(V): esta unidade caracteriza-se pelo relevo ondulado a fortemente ondulado, com colinas associadas a cerros e morrotes. O substrato desta unidade é constituído por arenitos e os solos são profundos sendo comum os Latossolos arenosos e junto aos cerros e morrotes ocorrem afloramento de rochas de arenitos. Nesta unidade ocorre predomínio de lavouras e em menor quantidade a presença de campos.

A unidade ocupa $4,92 \%$ da área total, e a preocupação desta unidade é o cuidado com os solos arenoso susceptível a processos erosivos. Os afloramentos de rochas impedem o uso de maquinário agrícola em algumas áreas. 
Unidade de Morrotes de Rocha Vulcânica(VI): esta unidade é bastante semelhante a unidade $\mathrm{V}$, pelas características do relevo, ondulado a fortemente ondulado, com colinas associadas a cerros e morrotes. O que difere é o substrato rochoso, que nesta unidade é constituída de rochas vulcânicas. Os solos são em geral rasos característicos de uma associação de Neossolo e Cambissolos. O uso predominante também difere, uma vez que os campos com criação de gado são os mais observados.

Esta unidade ocupa 3,68\% da área total e a preocupação desta unidade está associado a porções de fortes declividades com afloramento de blocos de rochas vulcânicas e onde podem ocorrer movimentos de massa se não respeitadas as áreas de preservação com manutenção das áreas vegetadas.

Unidade com Relevo Escarpado (VII): esta unidade caracteriza-se pelo relevo fortemente ondulado, com presença de vertentes escarpadas, localizadas principalmente no alto curso da bacia hidrográfica, junto às áreas de rebordo. O substrato é vulcânico do rebordo do planalto. Os solos são rasos e bastante pedregosos, com afloramento de blocos de rochas associados ao solo. $\mathrm{O}$ uso predominante de campos com associação, junto às áreas íngremes de mata nativa.

Esta unidade ocupa 19,65\% da área e o que se deve dar destaque é a preservada presença de mata nativa junto às áreas escarpada e de elevada declividade, o que contribui com o equilíbrio da vertente.

Unidade de Uso Urbano(VIII): esta unidade se caracteriza pelo uso urbano, sendo aqui destacada as áreas urbanas de Santiago e Nova Esperança, localizadas no alto curso da bacia hidrográfica do Rio Itu, sobre substratos vulcânicos, e solos rasos. As ocupações são caracterizadas como de áreas residenciais principalmente de casas.

Esta unidade ocupa $0,05 \%$ da área total e deve-se dar destaque a presença das grandes alterações ao meio que podem ser causadas pela ação antrópica, como modificações na fisiografia e fisiologia da paisagem através de cortes e aterros impermeabilização de terrenos, modificações na rede de drenagem, deposição de resíduos, etc.

Unidade com Processos de Arenização (IX): os areais por ser uma feição muito característica foram definidos como uma unidade isolada. Localizados principalmente nas nascentes do Arroio Puitã, sobre o substrato de arenitos friáveis. Associados aos cerros ocorrem pequenas florestas plantadas de pinus e eucaliptus com tendência à ampliação. 
Esta unidade ocupa $1,45 \%$ da área total, e deve-se destacar a grande fragilidade desta unidade gerando campos de areia muito susceptível aos processos de dinâmica superficial.

\section{CONSIDERAÇÕES FINAIS}

A crescente preocupação que esta sendo despertada junto à sociedade, principalmente nas últimas décadas, no que diz respeito ao uso e manejo indiscriminado dos recursos naturais, estão fazendo com que os estudos ambientais adquiram uma grande importância, principalmente no que se refere às questões de planejamentos e exploração destes recursos.

Dentro desta visão a Bacia Hidrográfica, tem sido vista como unidade essencial para a elaboração deste estudo, por ser uma unidade natural e permitir a análise de entrada e saída de elementos e neste sentido, o desenvolvimento de análise ambiental fornecem situações concretas de interpretações.

Entre os diversos parâmetros físicos, foram analisados na bacia hidrográfica do Rio Itu os atributos do relevo como as características das vertentes, drenagem, além das características de uso e ocupação da terra, características do solo, caracterização de precipitação, características ambientais marcantes e áreas de proteção.

Com o uso de programas SIG e da síntese cartográfica, o presente trabalho conseguiu definir nove unidade Geoambientais.

A síntese cartográfica representada pelas unidades Geoambientais é um elemento base para o desenvolvimento de trabalhos de planejamento. Além disso, propostas de gestão devem ter informações sobre o relevo e meio físico, permitindo estabelecer e compreender os processos de dinâmica superficial.

Devido a grande diversidade da bacia hidrográfica, a mesma necessita de um detalhado planejamento de uso e exploração, para que possa se estabelecer uma melhor relação entre as características naturais, com a forma de ocupação. As declividades predominantes são médias e baixas, proporciona uma melhor forma de uso para a agropecuária, porém este fator não deve ser o único a ser observado, pois um grande condicionador quanto à intensidade de uso a ser empregado nesta área são os substratos formadores dos solos e das rochas, os quais requerem os maiores cuidados quanto a análise dos processos de dinâmica superficial. 
As informações aqui contidas são importantes para o planejamento e manejo da bacia hidrográfica, e visam contribuir e servir de material de apoio à tomada de decisões junto aos municípios, além de acrescentar material cartográfico para uso da sociedade em geral e como fonte de dados para a comunidade local conhecer o lugar onde vivem.

\section{REFERÊNCIAS BIBLIOGRÁFICAS}

AGÊNCIA NACIONAL DAS AGUAS (ANA). Sistema de Informações Hidrológicas. Disponível em: <<http://hidroweb.ana.gov.br >>. Acesso em dezembro de 2006.

BERLATO, M. A.; FONTANA, D. C. El Nino e La Nina: Impactos no Clima, na Vegetação e na Agricultura do Rio Grande do Sul Aplicações de Previsões Climáticas na Agricultura. Porto Alegre: UFRGS. 2003. $110 \mathrm{p}$.

CARDOSO, C. B. Mapeamento das Unidades Geomorfológicas e os Impactos Ambientais: Bacias Hidrográficas do Arroio São João e Sanga da Divisa, Alegrete - RS. 2003. 90 p. Monografia (Graduação em Geografia), Santa Maria: UFSM. 2003.

CORRÊA, L. da S. L. Mapeamento Geológico Geomorfológico da Bacia Hidrográfica do Arroio Caraguataí, Manuel Viana, RS. 2004. 55p. Monografia (Graduação em Geografia), Santa Maria. 2004

EMPRESA BRASILEIRA DE PESQUISA AGROPECUÁRIA (EMBRAPA). Sistema Brasileiro de Classificação de Solos. Brasília: Embrapa Produção de Informação. 1999415 p.

EMPRESA BRASILEIRA DE PESQUISA AGROPECUÁRIA (EMBRAPA). Laboratório de Agrometeorologia. Disponível em <<http://www.cpact.embrapa.br/agromet $>>$. Acesso em dezembro de 2006.

KULMAN, D. Estudos Morfométricos da Bacia Hidrográfica do Arroio Jaguarí-Mirim, RS. 2004. 71 p. Monografia (Graduação em Geografia), Santa Maria. 2004.

PAULA, P. M. Mapeamento Geológico - Geomorfológico na Bacia do Lajeado Grande, Alegrete - RS. 2002. 61 p. Monografia (Graduação em Geografia), Santa Maria: UFSM. 2002.

ROSS, J. S. Registro Cartográfico dos Fatos Geomorfológicos e a Questão da Taxonomia do Relevo. Revista do Departamento de Geografia, n.6. São Paulo: FFLCH. 1992. p. 17-29.

SANGÓI, D. S.; TRENTIN, R.; ROBAINA, L. E. S.; PIRES, C. A. F. Mapeamento de "Landforms" na Bacia do Rio Inhacundá, São Francisco de Assis/RS. Geosul. Florianópolis. v.18, n.36, jul. dez 2003. p.151-167.

SOUTO, R. Deserto: Uma Ameaça?. Secretaria da Agricultura do RS, DRNR, Diretoria Geral, Porto Alegre. 1985. 177 p. 
STRECK, E. E.; KAMPF, N.; DALMOLIN, R. S. D.; KLAMT, E.; NASCIMENTO, P. C.; SCHNEIDER, P. Solos do Rio Grande do Sul. Porto Alegre: EMATER/RS; UFRGS. 2002. 107 p.

SUERTEGARAY, D. M. A. Deserto Grande do Sul: Controvérsias. Porto Alegre: Ed da Universidade /UFRGS. 1992. 109 p.

SUERTEGARAY, D. M. A.; GUASSELLI, L.; VERDUM, R. Atlas de Arenização: Sudoeste do Rio Grande do Sul. Porto Alegre: Secretaria da Coordenação e Planejamento. 2001. v. 1. Mapas.

TRENTIN, R. e ROBAINA, L. E. S. Metodologia para Mapeamento Geoambiental no Oeste do Rio Grande do Sul In: XI Simpósio Brasileiro de Geografia Física Aplicada: Anais. 2005. p. 3606 a 3615.

TRENTIN, R. Definição de Unidades Geoambientais na Bacia Hidrográfica do Rio Itu - Oeste do RS. 2007. 142 p. Dissertação (Dissertação de Mestrado). Santa Maria, 2007.

VERDUM, R. L'Approche Pour Comprendre la Dynamique du Milieu Dans Le Secteur de São Francisco de Assis tt Manuel Viana - Etat Du Rio Grande Do Sul - Bresil. 1993. 93 p. Dissertação (Dissertação de Mestrado). Université de Toulouse le Mirail, UTM, França. 1993.

VERDUM, R. Approche Geographique des Deserts Dans les Communes de Sao Francisco de Assis et Manuel Viana, Etat du Rio Grande do Sul, Bresil. 1997. 211 p. Tese (Tese de Doutorado). Université de Toulouse le Mirail, UTM, França. 1997.

Artigo recebido em 11/03/2012.

Artigo aceito em 25/04/2012. 